University of Nebraska - Lincoln

DigitalCommons@University of Nebraska - Lincoln

U.S. Department of Veterans Affairs Staff

Publications

U.S. Department of Veterans Affairs

2009

Hepatocyte growth factor protects hepatocytes against oxidative injury induced by ethanol metabolism

\author{
Argelia Valdés-Arzate \\ Universidad Autónoma Metropolitana-Iztapalapa \\ Armando Luna \\ Universidad Autónoma Metropolitana-Iztapalapa \\ Leticia Bucio \\ Universidad Autónoma Metropolitana-Iztapalapa \\ Cynthia Licona \\ Universidad Autónoma Metropolitana-Iztapalapa \\ Dahn L. Clemens \\ University of Nebraska Medical Center, dclemens@UNMC.edu \\ See next page for additional authors
}

Follow this and additional works at: https://digitalcommons.unl.edu/veterans

Valdés-Arzate, Argelia; Luna, Armando; Bucio, Leticia; Licona, Cynthia; Clemens, Dahn L.; Souza, Verónica; Hernandez, Elizabeth; Kershenobich, David; Gutiérrez-Ruiz, María Concepción; and Gómez-Quiroz, Luis Enrique, "Hepatocyte growth factor protects hepatocytes against oxidative injury induced by ethanol metabolism" (2009). U.S. Department of Veterans Affairs Staff Publications. 83.

https://digitalcommons.unl.edu/veterans/83

This Article is brought to you for free and open access by the U.S. Department of Veterans Affairs at DigitalCommons@University of Nebraska - Lincoln. It has been accepted for inclusion in U.S. Department of Veterans Affairs Staff Publications by an authorized administrator of DigitalCommons@University of Nebraska - Lincoln. 


\section{Authors}

Argelia Valdés-Arzate, Armando Luna, Leticia Bucio, Cynthia Licona, Dahn L. Clemens, Verónica Souza, Elizabeth Hernandez, David Kershenobich, María Concepción Gutiérrez-Ruiz, and Luis Enrique GómezQuiroz 


\title{
Hepatocyte growth factor protects hepatocytes against oxidative injury induced by ethanol metabolism
}

\author{
Argelia Valdés-Arzate ${ }^{\mathrm{a}, \mathrm{b}}$, Armando Luna ${ }^{\mathrm{a}, \mathrm{b}}$, Leticia Bucio ${ }^{\mathrm{a}}$, Cynthia Licona ${ }^{\mathrm{a}}$, Dahn L. Clemens ${ }^{\mathrm{c}}$, \\ Verónica Souza ${ }^{a}$, Elizabeth Hernandez ${ }^{\mathrm{a}}$, David Kershenobich ${ }^{\mathrm{d}}$, \\ María Concepción Gutiérrez-Ruiz a , Luis Enrique Gómez-Quiroz a,* \\ a Departamento de Ciencias de la Salud, DCBS, Universidad Autónoma Metropolitana-Iztapalapa, 09340 México, DF, México \\ b Posgrado en Biología Experimental, DCBS, Universidad Autónoma Metropolitana-Iztapalapa, 09340 México, DF, México \\ ${ }^{c}$ Research Service, The Veterans Affair Medical Center, and the University of Nebraska Medical Center, Omaha, NE 68198, USA \\ d Departamento de Medicina Experimental, Facultad de Medicina, Universidad Nacional Autónoma de México, México, DF, México
}

\section{A R T I C L E I N F O}

Article history:

Received 27 January 2009

Revised 7 May 2009

Accepted 13 May 2009

Available online 19 May 2009

\section{Keywords:}

Cytochrome P450 2E1

Oxidative stress

Alcoholic liver disease

Ethanol

HepG2

Free radicals

\begin{abstract}
A B S T R A C T
Hepatocyte growth factor (HGF) is involved in many cellular responses, such as mitogenesis and apoptosis protection; however, its effect against oxidative injury induced by ethanol metabolism is not well understood. The aim of this work was to address the mechanism of HGF-induced protection against ethanolgenerated oxidative stress damage in the human cell line VL-17A (cytochrome P450 2E1/alcohol dehydrogenase-transfected HepG2 cells). Cells were pretreated with $50 \mathrm{ng} / \mathrm{ml}$ HGF for $12 \mathrm{~h}$ and then treated with $100 \mathrm{mM}$ ethanol for 0-48 h. Some parameters of oxidative damage were evaluated. We found that ethanol induced peroxide formation (3.3-fold) and oxidative damage as judged by lipid peroxidation (5.4-fold). Damage was prevented by HGF. To address the mechanisms of HGF-induced protection we investigated the cellular antioxidant system. We found that HGF increased the GSH/GSSG ratio, as well as SOD1, catalase, and $\gamma$-glutamylcysteine synthetase expression. To explore the signaling pathways involved in this process, VL-17A cells were pretreated with inhibitors against PI3K, Akt, and NF-KB. We found that all treatments decreased the expression of the antioxidant enzymes, thus abrogating the HGF-induced protection against oxidative stress. Our results demonstrate that HGF protects cells from the oxidative damage induced by ethanol metabolism by a mechanism driven by NF-KB and PI3K/Akt signaling.
\end{abstract}

(C) 2009 Elsevier Inc. All rights reserved.
Ethanol (EtOH) abuse remains one of the main factors that cause liver injury. Alcoholic liver disease (ALD) is characterized by several distinct stages of injury ranging from steatosis to cirrhosis [1,2]. These deleterious effects are caused by products of EtOH metabolism such as acetaldehyde and reactive oxygen species (ROS) generated by EtOH metabolism [3]. EtOH is detoxified mainly by alcohol dehydrogenase $(\mathrm{ADH})$ and cytochrome P450 2E1 (Cyp2E1) [3] and both enzymes generate acetaldehyde, a highly toxic metabolite. Additionally, ethanol metabolism by Cyp2E1 generates large amounts of ROS, which can be involved in many harmful processes, such as lipid and protein oxidation, that can promote cellular dysfunction and eventually cell death by apoptosis or necrosis [3-6].

Liver cells possess a number of compensatory mechanisms to deal with ROS and their effects; among these are the induction of antiapoptotic and antioxidant proteins such as superoxide dismutase (SOD), catalase, glutathione peroxidase (GSHPx), and the tripeptide glutathione (GSH), as well as others [5,7]. These mechanisms are induced in response to the actions of some growth factors and cytokines that

\footnotetext{
* Corresponding author. Fax: +52 555844730.

E-mail address: legq@xanum.uam.mx (L.E. Gómez-Quiroz).
}

activate survival signaling pathways, such as phosphoinositol 3-kinase

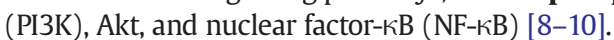

Hepatocyte growth factor (HGF), otherwise known as scatter factor, is a multifunctional growth factor that supports diverse cellular process including morphogenesis, motility, proliferation, and apoptosis protection [11]. HGF and its receptor c-Met activate signaling pathways that promote cell survival against apoptotic inducers, including the Fas agonist Jo2. There are several reports that strongly support the antiapoptotic effects of HGF/c-Met [8,12-14], mainly by the induction of antiapoptotic proteins such as Bcl-2, Bcl- $\mathrm{X}_{\mathrm{L}}$, or Mcl-1 $[14,15]$. Although the HGF/c-Met-induced apoptosis protection is well known, the effect on oxidative stress protection remains not fully understood. Some published reports indicate that HGF can protect from oxidative damage [15-17] but the effect of this growth factor on alcoholic liver damage is practically unexplored. Because ROS are thought to be important factors that induce cell injury in ALD, we investigated the capacity of HGF in the protection against ALD, using the recombinant HepG2 cell line VL-17A, which efficiently expresses both ADH and CYP2E1 [18]. We also investigated the mechanisms by which HGF protects cells from the deleterious effects of ROS produced as a result of ethanol metabolism. 


\section{Materials and methods}

\section{Cell culture}

HepG2 cells that constitutively and stably express ADH (VA-13) or both Cyp2E1 and ADH (VL-17A cells) were produced by Dr. Dahn L. Clemens from the Research Service, The Veterans Affair Medical Center, and the University of Nebraska Medical Center (Omaha, NE, USA). HepG2 cells were obtained from the American Type Culture Collection (Rockville, MD, USA). All cell lines were cultured in minimal essential medium containing $10 \%$ fetal bovine serum and supplemented with $100 \mathrm{U} / \mathrm{ml}$ penicillin and $100 \mu \mathrm{g} / \mathrm{ml}$ streptomycin in a humidified atmosphere in $5 \% \mathrm{CO}_{2}$ at $37^{\circ} \mathrm{C}$. Cells were plated and incubated in minimal essential medium overnight, the culture medium was replaced with fresh medium, and the various treatments were initiated.

\section{Experimental design}

Twenty-four hours after cell plating, the culture media were replaced with a serum-free medium containing or not containing $100 \mathrm{mM}$ EtOH. After incubation for $1,3,6,12,24$, or $48 \mathrm{~h}$, the cells were washed twice with phosphate-buffered saline (PBS), and whole-cell lysates (WCL) were prepared for Western blot analysis. For HGF pretreatments cells were treated for $12 \mathrm{~h}$ with $50 \mathrm{ng} / \mathrm{ml}$ recombinant human HGF (Peprotech, Rocky Hill, NJ, USA) and then $100 \mathrm{mM}$ EtOH was added to cell culture for $48 \mathrm{~h}$. At the end of treatment the cells were subjected to studies or harvested and prepared for Western blot analysis. To address the participation of some signaling pathways involved in cell survival, hepatocytes were pretreated for $30 \mathrm{~min}$ before HGF treatment with $10 \mathrm{mM}$ wortmannin, $10 \mu \mathrm{M}$ Akt inhibitor II, and $30 \mu \mathrm{M}$ SN50, a peptide inhibitor of NF-KB.

\section{Cell lysis and Western blot}

WCL were prepared from $1.5 \times 10^{6}$ cells that were collected and washed twice with ice-cold PBS. The cell pellet was resuspended in $150 \mu \mathrm{l}$ of M-PER (Pierce Chemical, Rockford, IL, USA) lysis buffer supplemented with proteases and phosphatase inhibitors. Lysis was performed on ice for $15 \mathrm{~min}$, and cell debris was removed by centrifugation at $13,000 \mathrm{~g}$ at $4^{\circ} \mathrm{C}$ for $10 \mathrm{~min}$. The supernatant was recovered and proteins were separated by electrophoresis using 4$20 \%$ gradient Duramide precast gels (Cambrex, Rockland, ME, USA) and transferred to a polyvinylidene difluoride membrane (Invitrogen, Carlsbad, CA, USA). Immunodetection was performed using primary antibody as indicated, anti-SOD1, anti-GSHPx $1 / 2$, anti-actin, $\gamma$ glutamylcysteine synthetase ( $\gamma$-GCS) (Santa Cruz Biotechnology, Santa Cruz, CA, USA), or anti-catalase (Sigma, St. Louis MO, USA), followed by horseradish peroxidase-conjugated secondary antibody (Amersham, Piscataway, NJ, USA) and detection by incubation with SuperSignal West Pico chemiluminescent substrate (Pierce) and HyperFilm (Amersham).

\section{Reactive oxygen species measurement}

Reactive oxygen species levels were determined using 6-carboxy$2^{\prime}, 7^{\prime}$-dichlorodihydrofluorescein diacetate (DCFH-DA) (Sigma). Cells were treated with $100 \mathrm{mM}$ EtOH for $24 \mathrm{~h}$ and then washed with icecold PBS and incubated with $3 \mu \mathrm{M}$ DCFH-DA for $30 \mathrm{~min}$. The cells were trypsinized and suspended in ice-cold PBS in the dark, and ROS generation was measured by flow cytometry using a flow cytometer (Becton-Dickinson). A minimum of 10,000 cell-gate events was acquired and analyzed with CellQuest (Becton-Dickinson) software.
Nuclear extract preparation

Cells were washed twice with ice-cold PBS and scraped off from dishes with a rubber cell lifter. Nuclear extracts were prepared by lysing cells with Igepal CA-630 (0.58\%) in $10 \mathrm{mM}$ Hepes, $\mathrm{pH} 7.9$, containing $10 \mathrm{mM} \mathrm{KCl}, 0.1 \mathrm{mM}$ EDTA, $0.1 \mathrm{mM}$ EGTA, $1 \mathrm{mM}$ dithiothreitol (DTT), $0.5 \mathrm{mM}$ phenylmethylsulfonyl fluoride (PMSF). Cells were vigorously mixed and centrifuged at $13,000 \mathrm{~g}$ at $4^{\circ} \mathrm{C}$. Pelleted nuclei were resuspended in $20 \mathrm{mM}$ Hepes, pH 7.9, containing $0.4 \mathrm{mM} \mathrm{NaCl}, 1 \mathrm{mM}$ EDTA, $1 \mathrm{mM}$ EGTA, 1 mM DTT, 1 mM PMSF. After being mixed continuously for $15 \mathrm{~min}$ at $4^{\circ} \mathrm{C}$ the samples were centrifuged at $13,000 \mathrm{~g}$ for $5 \mathrm{~min}$ and the supernatants recovered and stored at $-80^{\circ} \mathrm{C}$.

\section{Electrophoretic mobility shift assay}

Activation of NF- $\kappa$ B was examined by electrophoretic mobility shift assay (EMSA) using a consensus oligonucleotide, 5'-AGTTGAGGGGACTTTCCCAGGC-3' (Promega, Madison, WI, USA). Probe was labeled by T4 polynucleotide kinase (USB, Cleveland, OH, USA) with $\left[\gamma^{-}{ }^{32} \mathrm{P}\right]$ ATP $(3000 \mathrm{Ci} / \mathrm{mmol}$; MP Biomedical, Irvine, CA, USA). Labeled probe was purified using Bio-Spin 30 chromatography columns (Bio-Rad, Hercules, CA, USA). Binding reactions were done as described by Roman et al. [19] using $20 \mu \mathrm{g}$ of protein from nuclear extracts, in $5 \mu \mathrm{l}$ of incubation buffer ( $50 \mathrm{mM}$ Tris- $\mathrm{HCl}, \mathrm{pH} 7.5,200 \mathrm{mM} \mathrm{NaCl}, 5 \mathrm{mM}$ EDTA, $5 \mathrm{mM} \beta$-mercaptoethanol, and $20 \%$ glycerol) and $1 \mu \mathrm{g}$ poly (dI-dC). Complexes were separated through nondenaturing $6 \%$ polyacrylamide gels and were visualized by autoradiography. In competition experiments 100-fold molar excess of unlabeled oligonucleotide was added to the reaction mix for $5 \mathrm{~min}$ before addition of the labeled probe.

\section{Cell viability}

Cell viability was assessed by the crystal violet-staining assay according to Nakagawa et al. [20]. Cells seeded at $1 \times 10^{5}$ into 12 -wellplates were treated and then washed with PBS, fixed with $3.7 \%$ formaldehyde, and stained with $0.2 \%$ crystal violet. The absorbance of the $2 \%$ sodium dodecyl sulfate extracts was measured at $620 \mathrm{~nm}$. The cell viability was calculated as the percentage relative to untreated cells.

\section{5-Bromo-2'-deoxyuridine (BrdUrd) labeling}

Proliferation was analyzed by BrdUrd incorporation using a BrdUrd labeling kit (Roche Diagnostics GmbH, Mannheim, Germany). Cells were pretreated or not with $50 \mathrm{ng} / \mathrm{ml} \mathrm{HGF}$ for $12 \mathrm{~h}$ and then treated with or without $100 \mathrm{mM}$ EtOH for 24, 48, and $72 \mathrm{~h}$ and labeled with $10 \mu \mathrm{M}$ BrdUrd during the last $24 \mathrm{~h}$. Incorporation of BrdUrd was analyzed by luminescence using a multimode detector 880 (Beckman Coulter).

\section{GSH determination by HPLC}

GSH and oxidized GSH (GSSG) content was determined by HPLC following a protocol described by Fariss and Reed [21], with some modifications. Briefly, cells were collected in $1 \mathrm{ml}$ of $10 \%$ perchloric acid and sonicated on ice for $30 \mathrm{~s}$, and the suspension was centrifuged at $5000 \mathrm{~g}$, for $5 \mathrm{~min}$ at $4^{\circ} \mathrm{C}$. Two hundred fifty milliliters of the supernatant was removed and transferred to a fresh microcentrifuge tube for derivatization. Iodoacetic acid (100 mM) in $0.2 \mathrm{mM}$ m-cresol was added to each sample and to GSH and GSSG solution standards, the $\mathrm{pH}$ was adjusted to $9.0 \pm 0.2$ with a solution of $10 \mathrm{M} \mathrm{KOH} / 3 \mathrm{M} \mathrm{KHCO}_{3}$, and the samples were incubated in the dark at room temperature for $1 \mathrm{~h}$. After that, $1 \mathrm{ml}$ of $1 \% 1$-fluoro-2,4dinitrobenzene in 100\% HPLC-grade ethanol was added to each sample and incubated at room temperature and then at $4^{\circ} \mathrm{C}$ overnight. The next day, the samples were centrifuged at $13,000 \mathrm{~g}$ 
at room temperature for $1 \mathrm{~min}$ and $100 \mu \mathrm{N}$-DNP derivatives was injected into the loop of the HPLC system (Waters, Milford, MA, USA). Separation was achieved on a 3-aminopropyl column (5 $\mu \mathrm{m}$; $4.6 \mathrm{~mm} \times 20 \mathrm{~cm}$; Custom LC, Houston, TX, USA), with initial solvent conditions of $80 \%$ solution A ( $80 \%$ grade HPLC methanol), $20 \%$ solution B ( $0.5 \mathrm{M}$ sodium acetate in $64 \%$ methanol), which were maintained at $1 \mathrm{ml} / \mathrm{min}$ for $10 \mathrm{~min}$. From 10 to $40 \mathrm{~min}$, we a linear gradient was used, to a final ratio of $1 \%$ solution A/99\% solution B. Eluted $N$-DNP derivatives were measured by ultraviolet detection at $365 \mathrm{~nm}$.

\section{Lipid peroxidation}

Lipid peroxidation was assayed by determining the rate of production of thiobarbituric acid-reactive substances (TBARS) by spectrophotometry as described by Buege and Aust [22].

\section{Protein oxidation}

Oxidative modification of proteins generates protein carbonyl groups, which represent a hallmark of oxidation status of all proteins. Carbonyl groups were immunodetected using an Oxyblot kit (Chemicon) according to the manufacturer's instructions.

\section{Protein content determination}

Protein concentration was determined using a bicinchoninic acid kit (Pierce Chemical), according to the manufacturer's instructions.

\section{Data analysis}

Data are reported as means \pm SE. The SPSS package version 10 was used to run the analysis. Comparisons among groups were done by means of ANOVA. Tukey's method was used for multiple comparisons. A $p \leq 0.05$ was considered statistically significant.

\section{Results}

Ethanol metabolism induces oxidative damage

Hepatocytes metabolize EtOH mainly by the action of Cyp2E1 and $\mathrm{ADH}$. In vitro studies regarding this issue present a challenge because hepatocytes in primary culture rapidly lose the activity of both enzymes. To circumvent this problem we used the VL-17A cell line, which express both Cyp2E1 (Fig. 1A) and ADH, and the VA-13 [23] cell line, which expresses only ADH. It is well known that Cyp2E1 activity generates oxidative stress. Figs. $1 \mathrm{~B}$ and $\mathrm{C}$ show that $100 \mathrm{mM}$ EtOH induced ROS production (Fig. 1B) and lipid peroxidation (Fig. 1C) only in VL-17A cells in comparison with VA-13 and HepG2 cells. As further evidence of oxidative damage we assayed protein oxidation in WCL. Fig. 1D shows that EtOH treatment in VL-17A cells induced significant protein oxidation. These data are in agreement with many reports that Cyp2E1 is responsible for EtOH-induced oxidative damage [3,4]. No differences were observed in lipid peroxidation and ROS production in VA-13 and HepG2 cells (Figs. 1B and C), which confirms that ADH-mediated EtOH metabolism does not produce detectable levels of ROS.

\section{Cell injury induced by EtOH was prevented by HGF pretreatment}

To address the effects of HGF on EtOH-induced oxidative damage, VL-17A and HepG2 cells were pretreated or not with $50 \mathrm{ng} / \mathrm{ml} \mathrm{HGF}$ for $12 \mathrm{~h}$ and then exposed for $48 \mathrm{~h}$ to $100 \mathrm{mM}$ EtOH. HGF-induced protection was explored by examining culture morphology by microscopy. EtOH treatment damaged VL-17A cell culture (Fig. 2F) in comparison with untreated VL-17A (Fig. 2E) and EtOH-treated
HepG2 cells (Fig. 2B), which do not metabolize EtOH. HGF pretreatment abrogated the deleterious effects of EtOH metabolism, preventing cell damage (Fig. 2F). To confirm these observations we decided to determine protein oxidation and lipid peroxidation; results show that EtOH increased the content of carbonyl groups in WCL (Fig. 2I) and lipid peroxidation products (TBARS) 4.8-fold compared to untreated cells (Fig. 2J), which indicates an oxidative damage process. HGF pretreatment prevented the $\mathrm{EtOH}$ metabolism-induced oxidative damage to control values. These data are in agreement with the cell viability experiment determined by crystal violet-staining assay. EtOH decreased cell viability 35\% compared with untreated cells and HGF pretreatment protected cells against EtOH toxicity (Fig. 2K).
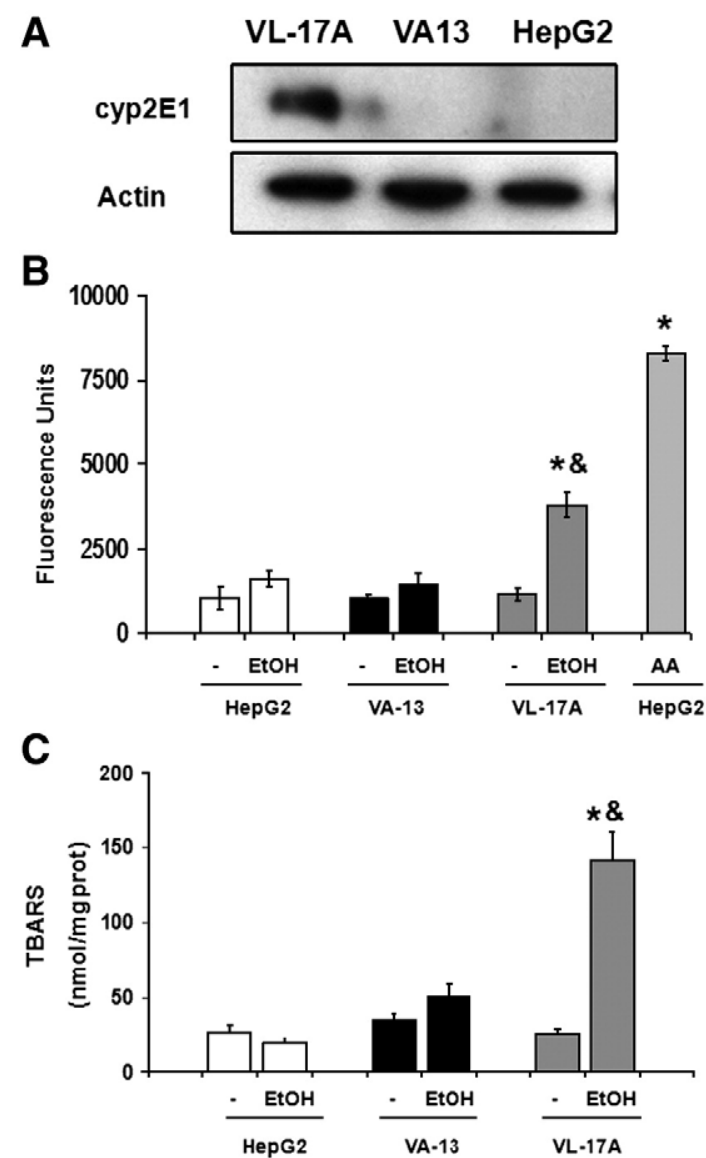

D

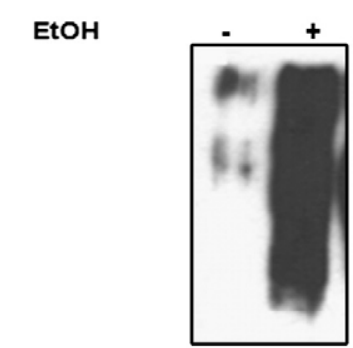

Fig. 1. Ethanol metabolism induces oxidative stress. VL-17A, VA-13, and HepG2 cells were treated or not with $100 \mathrm{mM}$ EtOH for $48 \mathrm{~h}$. (A) Whole-cell lysates prepared from serum-staved $(16 \mathrm{~h})$, untreated cells were immunoblotted with anti-cytochrome P450 $2 \mathrm{E} 1$ to determine the expression of the enzyme. (B) ROS determination. After EtOH treatment cells were incubated with the oxidative-sensitive probe DCFH-DA ( $3 \mu \mathrm{M})$ for $30 \mathrm{~min}$ and fluorescence was recorded by flow cytometry as indicated under Materials and methods. Antimycin A (AA) was used as a positive control. (C) Lipid peroxidation determined by the content of thiobarbituric acid-reactive substances (TBARS) as indicated under Materials and methods. (D) Protein oxidation determined by protein carbonyl group content. Each column represents the mean \pm SEM of at least three independent experiments. ${ }^{*} p<0.05$ against HepG2 treated with EtOH. ${ }^{\&} p<0.05$ against untreated VL-17A cells. 

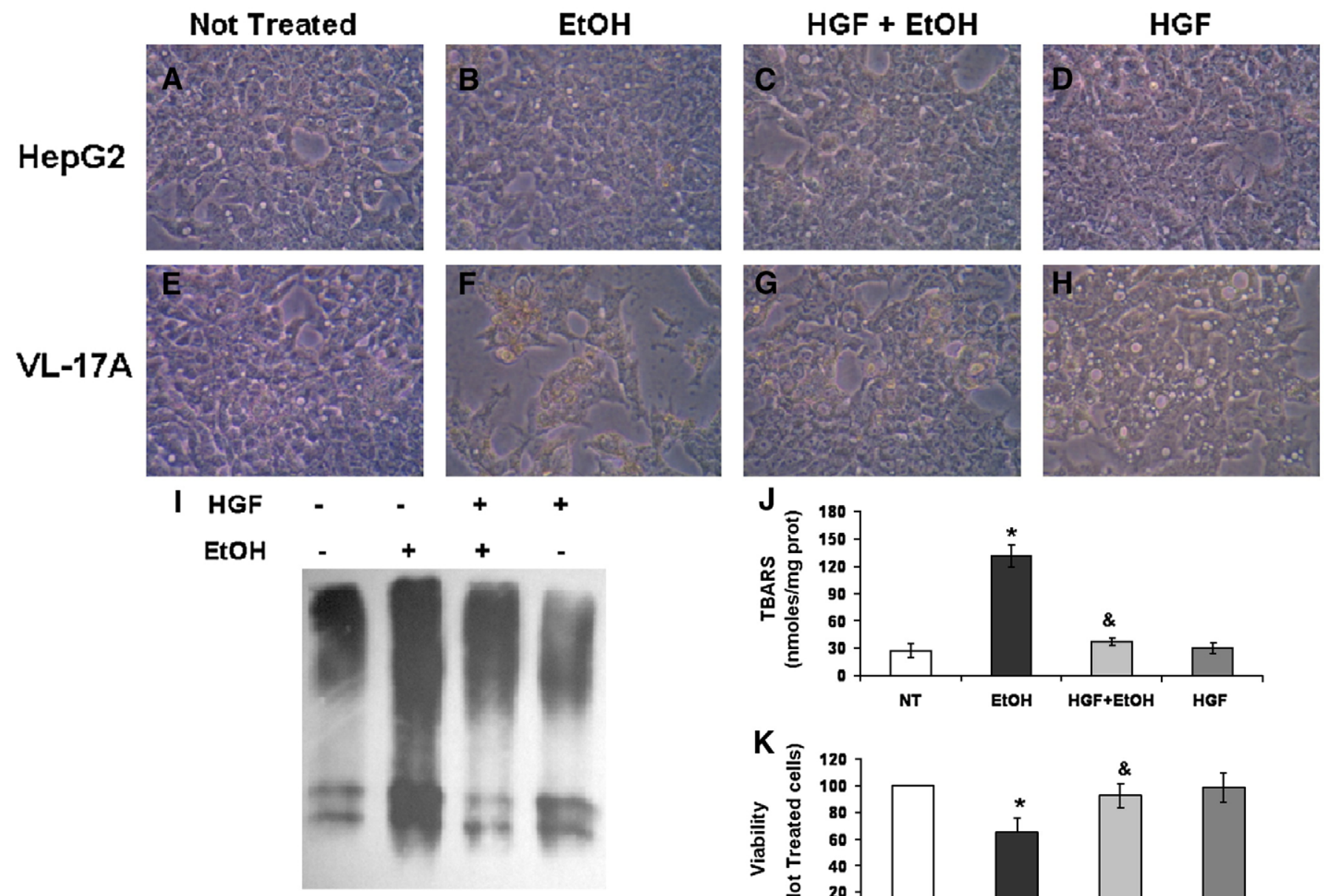

$\mathbf{J}$
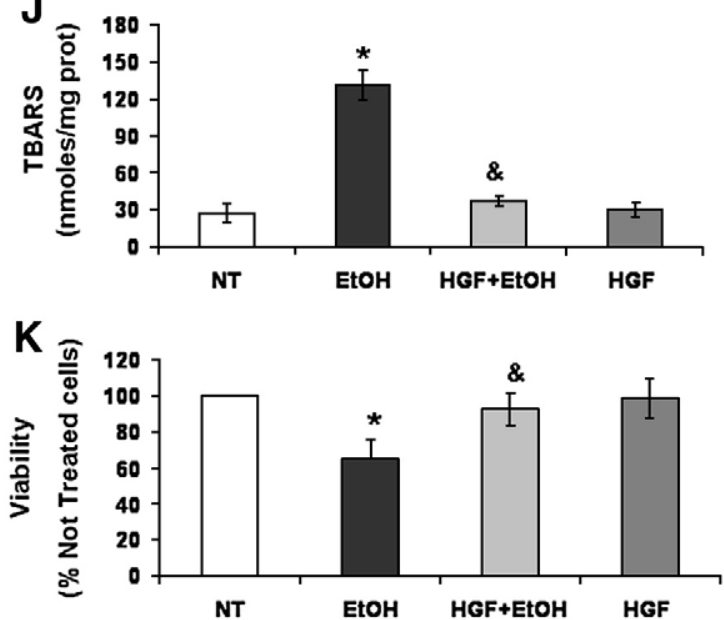

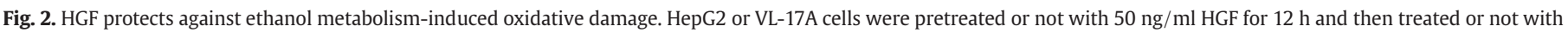

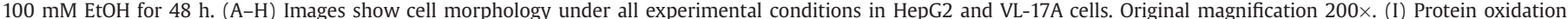

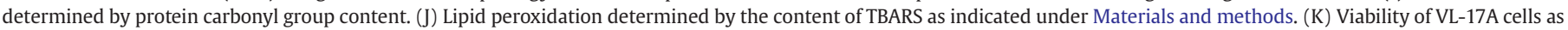

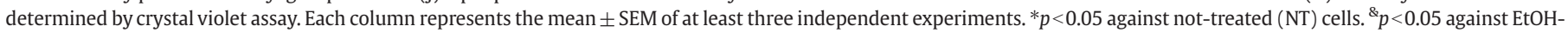
treated VL-17A cells.

\section{HGF induces cell survival by a mechanism mediated by NF- $\kappa B$}

To study whether HGF-induced protection is a process mediated by the well-known survival factor NF- $k$ B, we explored the activation of this transcription factor. HGF treatment in VL-17A cells exerted a time-dependent increase in DNA binding of NF- $\kappa B$ as early as $30 \mathrm{~min}$, which peaked at $120 \mathrm{~min}$ (Fig. 3A). To confirm this effect, we analyzed the degradation of the natural inhibitor of NF- $\kappa B($ I $\kappa B-\alpha)$ by Western blot. I $\mathrm{K} \mathrm{B}-\alpha$ content decreased in a time-dependent manner and was correlated with NF-kB activation (data not shown). To clarify that ethanol by itself does not induce NF- $\kappa$ B activation, we performed an EMSA with nuclear protein from hepatocytes treated with $100 \mathrm{mM}$ EtOH from 30 to $360 \mathrm{~min}$ (Fig. 3B), and no changes in the activation of NF- $\kappa B$ were observed. Furthermore we analyzed whether pretreatment with HGF for $2 \mathrm{~h}$ followed by treatment with EtOH for an additional $2 \mathrm{~h}$ could induce the activation of the transcription factor. Fig. $3 \mathrm{C}$ demonstrates that HGF + EtOH did not induce any change. To support the participation of NF- $\kappa$ B in HGFinduced cell protection, we determined cell viability by crystal violetstaining assay in cells pretreated for 30 min with SN50, a peptide inhibitor of NF-KB, and after that, we proceeded with the HGF and EtOH treatments, for 12 and 48 h, respectively. As Fig. 3D shows, SN50 inhibitor abrogated the protective effect of HGF, decreasing viability by $61 \%$ compared to HGF + EtOH treatment. This result confirms the participation of NF- $\kappa \mathrm{B}$ in the HGF-induced cell protection against oxidative stress generated by EtOH metabolism. The effect of SN50 on toxicity of EtOH alone was a slight decrease in viability in comparison with EtOH (data not shown) confirming that abrogation of basal NF-KB activity sensitizes cells to die.

\section{HGF-induced NF- $\kappa B$ activation is mediated by the PI3K/Akt pathway}

To address the signaling events underlying HGF-induced NF- $\kappa B$ activation, we decided to explore the inhibition of the main upstream steps that lead NF- $\kappa B$ activation. PI3K/Akt is the main signaling pathway that is activated by HGF and other growth factors $[8,10,24]$. VL-17A cells were pretreated for 30 min with wortmannin, Akt inhibitor, and SN50 inhibitor as a positive control and then treated with $50 \mathrm{ng} / \mathrm{ml} \mathrm{HGF}$ for $120 \mathrm{~min}$, and then EMSA was performed. As Fig. 4 shows, both wortmannin and Akt inhibitor abrogated HGFinduced NF- $\mathrm{B}$ B activation, suggesting that PI3K and Akt are involved in NF- $\kappa$ B activation.

\section{HGF enhances the antioxidant system to deal with EtOH toxicity}

Because GSH is the main hepatoprotector molecule in the liver, we decided to explore the GSH/GSSG ratio and the expression of $\gamma$-GCS, the key-step enzyme in GSH synthesis. Fig. 5A shows that HGF increased the GSH/GSSG ratio by 3-fold in comparison with untreated cells. These data are in agreement with $\gamma$-GCS content determined by 
A

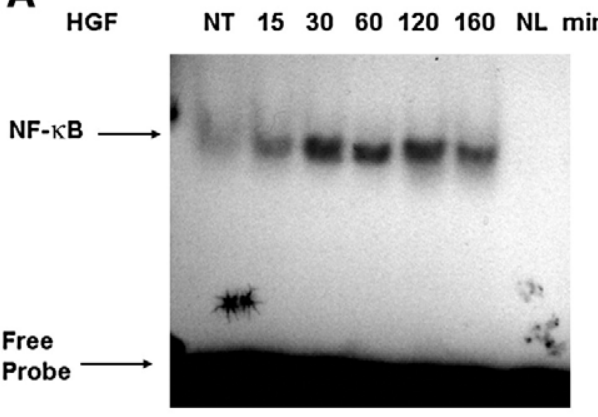

B

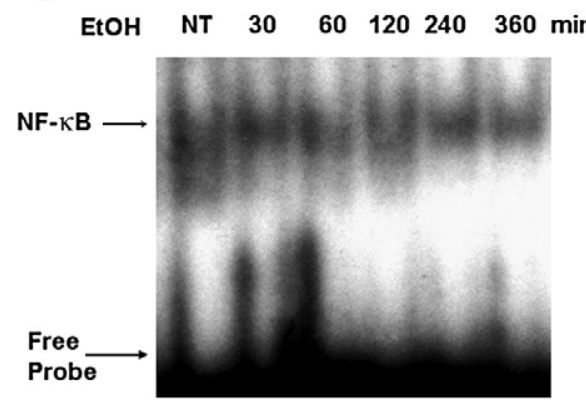

C

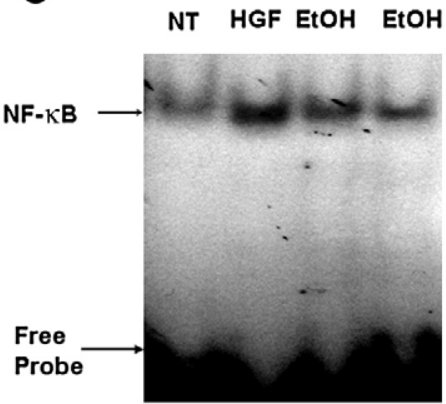

D

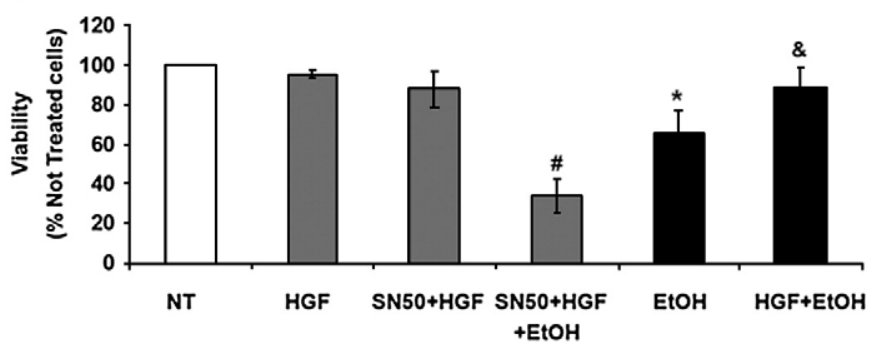

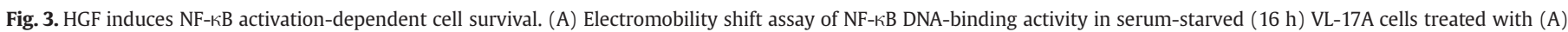

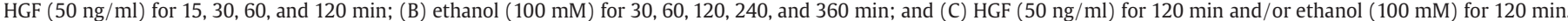

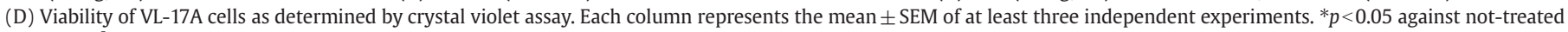
(NT) cells. ${ }^{\&} p<0.05$ against HGF + EtOH-treated cells. $\# p<0.05$ against EtOH-treated VL-17A cells.

Western blot (Fig. 5B), by which HGF treatment induced the enzyme 2.8-fold compared to untreated cells. EtOH treatment decreased the GSH/GSSG ratio, but the pretreatment with HGF in the presence of EtOH restored the ratio to control levels (Fig. 5C).

In addition to the GSH system we investigated the expression of the antioxidant proteins SOD1, catalase, and GSHPx $1 / 2$ by Western blot. HGF induced the expression of SOD1 and catalase (Fig. 6A), but failed to induce GSHPx 1/2 (data not shown). The expression of SOD1 and catalase was time-dependent and peaked at $12 \mathrm{~h}$ of HGF exposure (2.2- and 2.5-fold, respectively) and was associated with the cytoprotective effect observed in Figs. $2 \mathrm{H}$, I, J, and $\mathrm{K}$. To address the participation of $\mathrm{PI} 3 \mathrm{~K} / \mathrm{Akt} / \mathrm{NF}-\kappa \mathrm{B}$ signaling in the regulation of

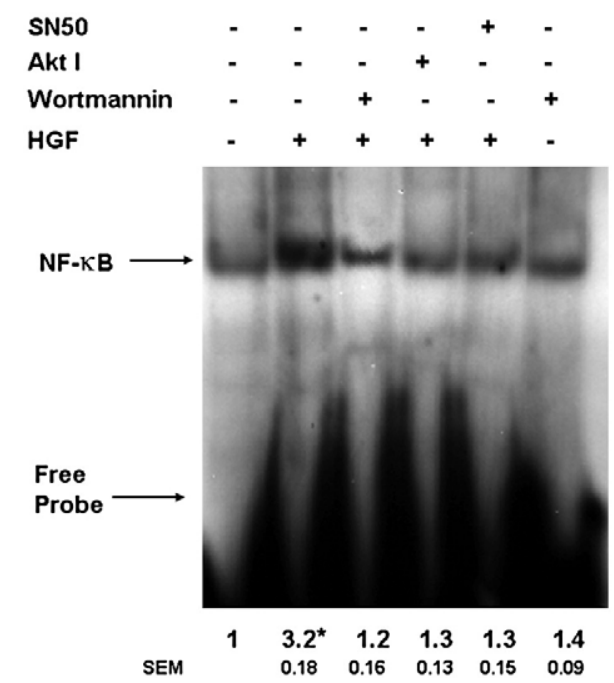

Fig. 4. HGF-induced NF- $\kappa B$ activation is mediated by PI3K and Akt. Electromobility shift assay of NF-KB DNA binding activity in serum-starved (16 h) cells. VL-17A cells were pretreated with $100 \mathrm{nM}$ wortmannin, $10 \mu \mathrm{M}$ Akt inhibitor II, or $30 \mu \mathrm{M}$ SN50 for $30 \mathrm{~min}$ and then treated with $\operatorname{HGF}(50 \mathrm{ng} / \mathrm{ml})$ for $2 \mathrm{~h}$. Image is representative of at least three independent experiments. ${ }^{*} p<0.05$ against untreated cells. antioxidant enzymes we pretreated cells with $10 \mathrm{mM}$ wortmannin, $10 \mu \mathrm{M}$ Akt inhibitor II, and $30 \mu \mathrm{M}$ SN50. The three inhibitors abrogated the HGF-induced catalase, SOD1, and $\gamma$-GCS (Fig. 6B). These data suggest that HGF transduces its antioxidant response via the PI3K/ Akt/NF-kB signaling pathway.

\section{HGF improves the EtOH-mediated impairment of cell proliferation}

Finally, to correlate the molecular findings with a physiological process we analyzed cell proliferation, because it is well known that EtOH impairs cell proliferation [25]. As Fig. 7 shows, EtOH decreased proliferation at $48 \mathrm{~h}$ of treatment compared to untreated cells, whereas HGF pretreatment moderated this effect significantly.

\section{Discussion}

Alcohol-induced damage is a multifactorial process that involves genetic and environmental factors. Some of these factors are ROS derived from Cyp2E1-mediated EtOH metabolism in addition to those generated by mitochondrial dysfunction [26]. Cyp2E1 activity is increased by 10 - to 20 -fold in the livers of alcohol-treated rodents [27]. In humans an increase has been observed, not only in alcohol abusers, but also in moderate alcohol consumers [28]. This overactivity of Cyp2E1 in ALD is tightly linked to ROS production and cell damage $[3,4,29,30]$, as we confirmed in this work. The recombinant HepG2 cells VL-17A, which express Cyp2E1 and alcohol dehydrogenase, presented oxidative damage when they were treated with $100 \mathrm{mM} \mathrm{EtOH}$ for $48 \mathrm{~h}$ (Figs. 1 and 2F), in comparison with untreated VL-17A cells or HepG2 cells that lack Cyp2E1 activity. Venugopal et al. [30] reported that VL17A cells treated with $100 \mathrm{mM}$ EtOH generate ROS that activate PKC $\delta$ and proteasome-mediated degradation of mitogen-activated protein kinase (MAPK) phosphatase-1, a protein phosphatase involved in c-Jun $\mathrm{N}$-terminal kinase dephosphorylation, leading a sustained activation of this kinase and apoptosis progression.

To deal with oxidative stress, hepatocytes have available a wide range of antioxidants and survival factors that are induced by changes in the redox status as an adaptation response and by growth factors as 

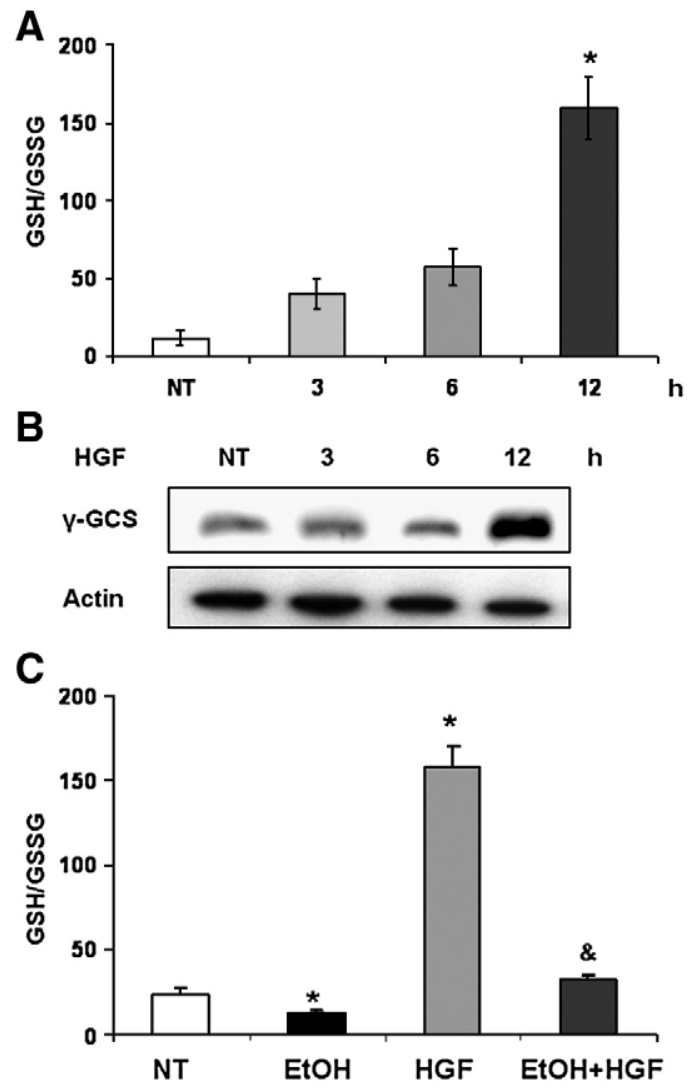

Fig. 5. HGF increases GSH synthesis. (A) The ratio of reduced glutathione (GSH) to oxidized glutathione (GSSG) determined by HPLC in serum-starved cells that were treated with HGF (50 ng/ml) for 0-12 h. Each column represents the mean \pm SEM of three independent experiments. ${ }^{*} p<0.05$ against untreated cells. (B) Expression of $\gamma$ glutamylcysteine synthetase $(\gamma$-GCS). Whole-cell lysates prepared from VL-17A cells treated with $\mathrm{HGF}(50 \mathrm{ng} / \mathrm{ml})$ at $0,3,6$, and $12 \mathrm{~h}$ were immunoblotted with anti- $\gamma$-GCS. A representative Western blot of three experiments is shown. (C) The ratio of GSH/ GSSG in hepatocytes treated or not with HGF $(50 \mathrm{ng} / \mathrm{ml})$ for $12 \mathrm{~h}$, or ethanol (100 mM) for $48 \mathrm{~h}$, or the combination of both. Each column represents the mean \pm SEM of three independent experiments. ${ }^{*} p<0.05$ against untreated cells. ${ }^{*} p<0.05$ against EtOHtreated cells.

survival responses. Recently it has been proposed that HGF and its receptor c-Met can regulate the expression of many genes involved in oxidative stress regulation [31] and even in the regulation of oxidative stress-related carcinogenesis [17]; however, the mechanism is not fully characterized. We observed that pretreatment with HGF protects hepatocytes against oxidative damage induced by EtOH (Fig. 2), which is in agreement with the effect observed in other cell types $[7,15,16]$.

It is well known that HGF can activate NF- $\kappa B$, a key downstream regulatory factor of cell survival [32,33], so we decided to explore the activation of this transcription factor in VL-17A cells treated with HGF. Our data revealed that HGF induced NF- $\kappa \mathrm{B}$ activation as rapidly as 30 min after treatment; this result is in agreement with those reported by Fan et al. [32]. These results suggest that HGF exerts a rapid response of cell survival, mediated by NF- $\kappa \mathrm{B}$, preparing the cells to deal with insults such as apoptosis inducers [12], hypoxia/reoxygenation-induced oxidative stress [24], or alcohol metabolism-mediated damage as we presented in this work.

Our data suggest that this response was mediated by PI3K and Akt activation. It is well documented that this pathway modulates many functions related to cell survival, proliferation, and liver regeneration [34] by activating downstream mediators and transcription factor such as MAPK, the signal transducers and activator of transcription proteins, and NF-kB [35]. All of these downstream kinases are able to regulate antiapoptotic response, proliferation, and regeneration, but in terms of antioxidant defense are not fully characterized.
A

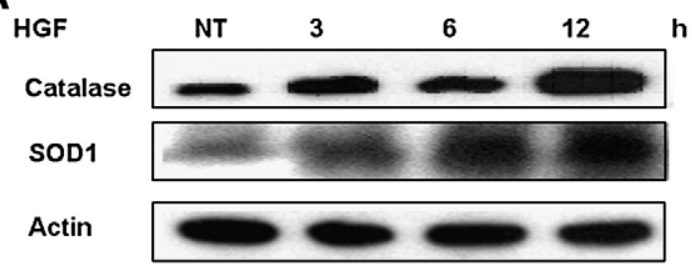

B

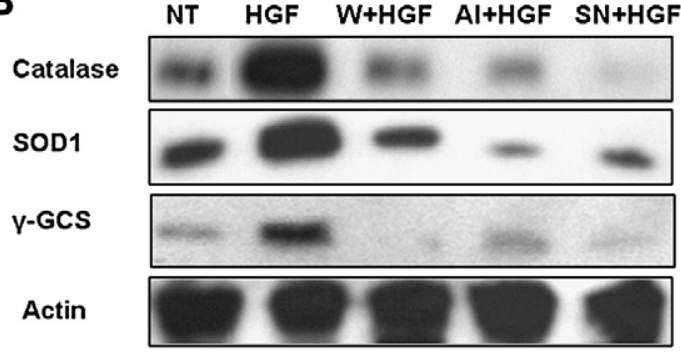

Fig. 6. HGF enhances the main antioxidant enzymes. (A) Expression of catalase and SOD1. Whole-cell lysates prepared from VL-17A cells treated with $\operatorname{HGF}(50 \mathrm{ng} / \mathrm{ml}$ ) for 0 , 3,6 , and 12 h were immunoblotted with anti-catalase and anti-SOD1. A representative Western blot of three experiments is shown. (B) VL-17A cells were pretreated with the PI3K inhibitor wortmannin (W; $100 \mathrm{nM}$ ), Akt inhibitor II (AI; $10 \mu \mathrm{M})$, or NF-KB inhibitor SN50 (SN; $30 \mu \mathrm{M})$ for $30 \mathrm{~min}$ and then treated with $\operatorname{HGF}(50 \mathrm{ng} / \mathrm{ml})$ for $12 \mathrm{~h}$. Antioxidant enzymes were immunoblotted with anti-catalase and anti-SOD1. A representative Western blot of three experiments is shown.

GSH is the main antioxidant protector against oxidative stress in the liver and its relevance in ALD [26] and other pathologies has been well documented. GSH is synthesized in the cytosol as a response to many signals, including oxidative stress and growth factors [6]. Tsuboi [36] reported that HGF treatment increased GSH synthesis in rat hepatocytes via induction of $\gamma$-GCS. Our data are in agreement with these observations; HGF treatment increased the GSH/GSSG ratio in VL-17A cells as well as $\gamma$-GCS expression and these effects were correlated with cell survival (Fig. 2K). Furthermore, recently Takami et al. [17] found that c-Met knockout mice present a disruption in redox homeostasis, which conditioned them to $\mathrm{N}$-nitrosodiethylamineinduced hepatocarcinogenesis. This effect was abrogated with oral administration of $N$-acetyl-L-cysteine (NAC), a well-known GSH precursor and antioxidant. The same result was observed in c-Met knockout hepatocytes that present an enhanced sensitization to Fasinduced apoptosis, which was abrogated by NAC treatment [37]. On the other hand, it has been reported that HGF can induce gene

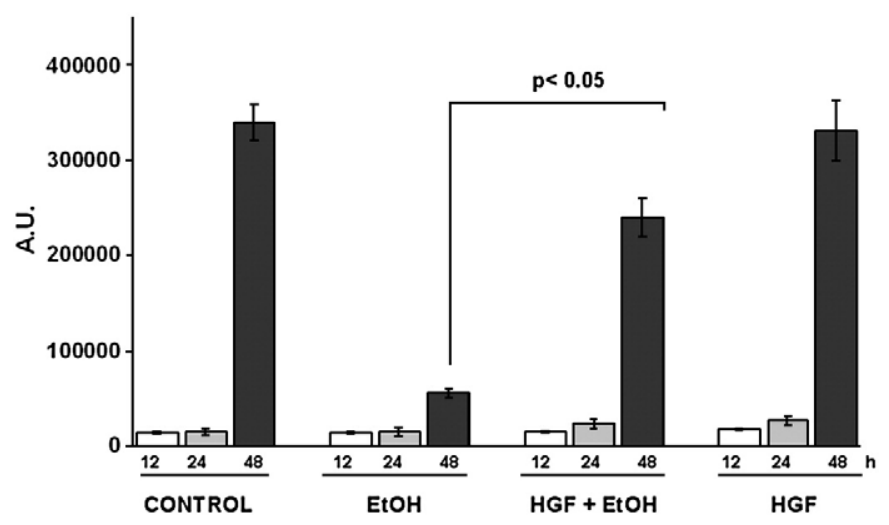

Fig. 7. HGF improves the EtOH-mediated impairment of cell proliferation. Proliferation was analyzed by BrdUrd incorporation using a BrdUrd labeling kit. VL-17A cells were pretreated or not with $50 \mathrm{ng} / \mathrm{ml} \mathrm{HGF}$ for $12 \mathrm{~h}$ and then treated with or without $100 \mathrm{mM}$ EtOH for 24, 48, and $72 \mathrm{~h}$ and labeled with $10 \mu \mathrm{M}$ BrdUrd during the last $24 \mathrm{~h}$. Incorporation of BrdUrd was analyzed by luminescence. Each column represents the mean \pm SEM of six independent experiments. 
expression of $\gamma$-GCS in bile duct epithelial cells [7] and an increased GSH synthesis in rat hepatocytes and H4IIE cells [33,36]. It is clear that GSH homeostasis is one of the main survival systems that are modulated by HGF in response to oxidative stress.

In addition to GSH synthesis and $\gamma$-GCS expression promoted by HGF, our data revealed that some antioxidant proteins are induced by the action of this growth factor. HGF stimulated the expression of the main antioxidant proteins such as SOD1 and catalase, but failed for GSHPx. Recently it has been published that in bile duct epithelial cells, HGF induced the expression of $\gamma$-GCS and GSH reductase, whereas no effect was observed for SOD1, catalase, and GSHPx [7]. This differential gene expression suggests that HGF activities are cell-type-dependent, even in liver cell populations. Hepatocytes are the main cell type that detoxifies $\mathrm{EtOH}$, and it is in these cells that more antioxidant protection is needed in addition to the GSH system.

In conclusion, this work sustains the predominant role of HGF in the antioxidant protection against EtOH-induced oxidative stress, by a mechanism dependent on the activation of the PI3K/Akt/NF- $\mathrm{KB}$ signaling pathway.

\section{Acknowledgments}

This work was partially funded by grants from the Consejo Nacional de Ciencia y Tecnología (CONACYT 61544 and 45921); by FUNDHEPA and FUNSALUD grants from Antonio Ariza Cañadilla, Secretaría de Educación Pública (PIFI2006-35-129-346/CA 14200635-40); and by the Universidad Autónoma Metropolitana-Iztapalapa. We thank CONACYT for financial support to Argelia Valdés-Arzate for her Ph.D. studies. We also thank Snorri S. Thorgeirsson and Valentina Factor, from the National Cancer Institute, National Institutes of Health, USA, for invaluable guidance in the field of c-Met/HGF.

\section{References}

[1] Zakhari, S.; Li, T. K. Determinants of alcohol use and abuse: impact of quantity and frequency patterns on liver disease. Hepatology 46:2032-2039; 2007.

[2] Nagata, K.; Suzuki, H.; Sakaguchi, S. Common pathogenic mechanism in development progression of liver injury caused by non-alcoholic or alcoholic steatohepatitis. J. Toxicol. Sci. 32:453-468; 2007.

[3] Lu, Y.; Cederbaum, A. I. CYP2E1 and oxidative liver injury by alcohol. Free Radic. Biol. Med. 44:723-738; 2007.

[4] Wu, D.; Cederbaum, A. I. Oxidative stress-mediated toxicity exerted by ethanolinducible CYP2E1. Toxicol. Appl. Pharmacol. 207:70-76; 2005.

[5] Albano, E. Alcohol, oxidative stress and free radical damage. Proc. Nutr. Soc. 65: 278-290; 2006.

[6] Garcia-Ruiz, C.; Fernandez-Checa, J. C. Redox regulation of hepatocyte apoptosis. J. Gastroenterol. Hepatol. 22 (Suppl. 1):S38-42; 2007.

[7] Arends, B.; Slump, E.; Spee, B.; Rothuizen, J.; Penning, L. C. Hepatocyte growth factor improves viability after $\mathrm{H}_{2} \mathrm{O}_{2}$-induced toxicity in bile duct epithelial cells. Comp. Biochem. Physiol. C Toxicol. Pharmacol. 147:324-330; 2007.

[8] Suzuki, A.; Hayashida, M.; Kawano, H.; Sugimoto, K.; Nakano, T.; Shiraki, K. Hepatocyte growth factor promotes cell survival from Fas-mediated cell death in hepatocellular carcinoma cells via Akt activation and Fas-death-inducing signaling complex suppression. Hepatology 32:796-802; 2000.

[9] Carmona-Cuenca, I.; Herrera, B.; Ventura, J. J.; Roncero, C.; Fernandez, M.; Fabregat, I. EGF blocks NADPH oxidase activation by TGF-beta in fetal rat hepatocytes, impairing oxidative stress, and cell death. J. Cell. Physiol. 207:322-330; 2006.

[10] Furge, K. A.; Zhang, Y. W.; Vande Woude, G. F. Met receptor tyrosine kinase: enhanced signaling through adapter proteins. Oncogene 19:5582-5589; 2000.

[11] Zarnegar, R.; Michalopoulos, G. K. The many faces of hepatocyte growth factor: from hepatopoiesis to hematopoiesis. J. Cell Biol. 129:1177-1180; 1995.

[12] Huh, C. G.; Factor, V. M.; Sanchez, A.; Uchida, K.; Conner, E. A.; Thorgeirsson, S. S. Hepatocyte growth factor/c-met signaling pathway is required for efficient liver regeneration and repair. Proc. Natl. Acad. Sci. USA 101:4477-4482; 2004.

[13] Xiao, G. H.; Jeffers, M.; Bellacosa, A.; Mitsuuchi, Y.; Vande Woude, G. F.; Testa, J. R. Anti-apoptotic signaling by hepatocyte growth factor/Met via the phosphatidylinositol 3-kinase/Akt and mitogen-activated protein kinase pathways. Proc. Natl. Acad. Sci. USA 98:247-252; 2001.
[14] Schulze-Bergkamen, H.; Brenner, D.; Krueger, A.; Suess, D.; Fas, S. C.; Frey, C. R. Dax, A.; Zink, D.; Buchler, P.; Muller, M.; Krammer, P. H. Hepatocyte growth factor induces Mcl-1 in primary human hepatocytes and inhibits CD95-mediated apoptosis via Akt. Hepatology 39:645-654; 2004.

[15] Okada, M.; Sugita, K.; Inukai, T.; Goi, K.; Kagami, K.; Kawasaki, K.; Nakazawa, S. Hepatocyte growth factor protects small airway epithelial cells from apoptosis induced by tumor necrosis factor-alpha or oxidative stress. Pediatr. Res. 56: 336-344; 2004.

[16] Li, H.; Jiang, T.; Lin, Y.; Zhao, Z.; Zhang, N. HGF protects rat mesangial cells from high-glucose-mediated oxidative stress. Am. J. Nephrol. 26:519-530; 2006.

[17] Takami, T.; Kaposi-Novak, P.; Uchida, K.; Gomez-Quiroz, L. E.; Conner, E. A.; Factor V. M.; Thorgeirsson, S. S. Loss of hepatocyte growth factor/c-Met signaling pathway accelerates early stages of $\mathrm{N}$-nitrosodiethylamine induced hepatocarcinogenesis. Cancer Res. 67:9844-9851; 2007.

[18] Donohue, T. M.; Osna, N. A.; Clemens, D. L. Recombinant Hep G2 cells that express alcohol dehydrogenase and cytochrome P450 2E1 as a model of ethanol-elicited cytotoxicity. Int. J. Biochem. Cell Biol. 38:92-101; 2006.

[19] Roman, J.; Gimenez, A.; Lluis, J. M.; Gasso, M.; Rubio, M.; Caballeria, J.; Pares, A.; Rodes, J.; Fernandez-Checa, J. C. Enhanced DNA binding and activation of transcription factors NF-kappa B and AP-1 by acetaldehyde in HEPG2 cells. J. Biol. Chem. 275:14684-14690; 2000.

[20] Nakagawa, T.; Sawada, M.; Gonzalez, F. J.; Yokoi, T.; Kamataki, T. Stable expression of human CYP2E1 in Chinese hamster cells: high sensitivity to N,N-dimethylnitrosamine in cytotoxicity testing. Mutat. Res. 360:181-186; 1996.

[21] Fariss, M. W.; Reed, D. J. High-performance liquid chromatography of thiols and disulfides: dinitrophenol derivatives. Methods Enzymol. 143:101-109; 1987.

[22] Buege, J.; Aust, S. Microsomal lipid peroxidation. Methods Enzymol. 52:302-310; 1978.

[23] Clemens, D. L.; Forman, A.; Jerrells, T. R.; Sorrell, M. F.; Tuma, D. J. Relationship between acetaldehyde levels and cell survival in ethanol-metabolizing hepatoma cells. Hepatology 35:1196-1204; 2002.

[24] Ozaki, M.; Haga, S.; Zhang, H. Q.; Irani, K.; Suzuki, S. Inhibition of hypoxia/ reoxygenation-induced oxidative stress in HGF-stimulated antiapoptotic signaling: role of PI3-K and Akt kinase upon rac1. Cell Death Differ. 10:508-515; 2003.

[25] Saso, K.; Higashi, K.; Nomura, T.; Hoshino, M.; Ito, M.; Moehren, G.; Hoek, J. B. Inhibitory effect of ethanol on hepatocyte growth factor-induced DNA synthesis and $\mathrm{Ca}^{2+}$ mobilization in rat hepatocytes. Alcohol Clin. Exp. Res. 20:330A-334A; 1996.

[26] Fernandez-Checa, J. C.; Kaplowitz, N. Hepatic mitochondrial glutathione: transport and role in disease and toxicity. Toxicol. Appl. Pharmacol. 204:263-273; 2005.

[27] Ronis, M.; Lindros, K.; Ingelman-Sundberg, M. The CYP2E1 family. In: Ionides, C. Ed. Cytochromes P450: Metabolic and Toxicological Aspects. CRC Press: Boca Raton, Fla. 211-239; 1996

[28] Girre, C.; Lucas, D.; Hispard, E.; Menez, C.; Dally, S.; Menez, J. F. Assessment of cytochrome P4502E1 induction in alcoholic patients by chlorzoxazone pharmacokinetics. Biochem. Pharmacol. 47:1503-1508; 1994.

[29] Osna, N. A.; Clemens, D. L.; Donohue Jr, T. M. Interferon gamma enhances proteasome activity in recombinant Hep G2 cells that express cytochrome P4502E1: modulation by ethanol. Biochem. Pharmacol. 66:697-710; 2003.

[30] Venugopal, S. K.; Chen, J.; Zhang, Y.; Clemens, D.; Follenzi, A.; Zern, M. A. Role of MAPK phosphatase-1 in sustained activation of JNK during ethanol-induced apoptosis in hepatocyte-like VL-17A cells. J. Biol. Chem. 282:31900-31908; 2007.

[31] Kaposi-Novak, P.; Lee, J. S.; Gomez-Quiroz, L.; Coulouarn, C.; Factor, V. M.; Thorgeirsson, S. S. Met-regulated expression signature defines a subset of human hepatocellular carcinomas with poor prognosis and aggressive phenotype. J. Clin. Invest. 116:1582-1595; 2006.

[32] Fan, S.; Gao, M.; Meng, Q.; Laterra, J. J.; Symons, M. H.; Coniglio, S.; Pestell, R. G.; Goldberg, I. D.; Rosen, E. M. Role of NF-kappaB signaling in hepatocyte growth factor/scatter factor-mediated cell protection. Oncogene 24:1749-1766; 2005.

[33] Yang, H.; Magilnick, N.; Xia, M.; Lu, S. C. Effects of hepatocyte growth factor on glutathione synthesis, growth, and apoptosis is cell density-dependent. Exp. Cell Res. 314:398-412; 2008.

[34] Imose, M.; Nagaki, M.; Naiki, T.; Osawa, Y.; Brenner, D. A.; Asano, T.; Hayashi, H.; Kato, T.; Moriwaki, H. Inhibition of nuclear factor kappaB and phosphatidylinositol 3-kinase/Akt is essential for massive hepatocyte apoptosis induced by tumor necrosis factor alpha in mice. Liver Int. 23:386-396; 2003.

[35] Lu, Y.; Zhou, J.; Xu, C.; Lin, H.; Xiao, J.; Wang, Z.; Yang, B. JAK/STAT and PI3K/AKT pathways form a mutual transactivation loop and afford resistance to oxidative stress-induced apoptosis in cardiomyocytes. Cell Physiol. Biochem. 21:305-314; 2008.

[36] Tsuboi, S. Elevation of glutathione level in rat hepatocytes by hepatocyte growth factor via induction of gamma-glutamylcysteine synthetase. J. Biochem. 126: 815-820; 1999.

[37] Gomez-Quiroz, L. E.; Factor, V. M.; Kaposi-Novak, P.; Coulouarn, C.; Conner, E. A.; Thorgeirsson, S. S. Hepatocyte-specific c-Met deletion disrupts redox homeostasis and sensitizes to Fas-mediated apoptosis. J. Biol. Chem. 283:14581-14589; 2008. 